\title{
PENGARUH SKEPTISISME PROFESIONAL AUDITOR, KOMPETENSI, INDEPENDENSI DAN KOMPLEKSITAS AUDIT TERHADAP KUALITAS AUDIT
}

\author{
Suci Nugrahaeni \\ Samin \\ Anita Nopiyanti \\ Universitas Pembangunan Nasional "Veteran" Jakarta \\ Sucinugrahaeni@gmail.com
}

\begin{abstract}
This study was conducted with the aim to examine the influence of The Auditor's Professional Skepticism, Competence, Independence and Complexity of The Audit on Audit Quality. The sample used in this study is 70 auditor by using purposive sampling method. The analysis technique that used in this study is multiple linear regression with significance level of 5\%. The results of this study indicate that the value of Adjusted R Square is 0.547 or $54,7 \%$ which means that the ability of independent variables namely the Auditor's Professional Skepticism, Competence, Independence and Complexity Audit in explaining the dependent variable that is Audit Quality is 54,7\% and the rest 45,3\% is explained by other variables outside of that variables used in this study. The results of this study also show that (1) The Auditor's Professional Skepticism has significant effect on Audit Quality because it has a significance value lower than the level of significance of 5\% that is equal to 0,002 or $0,2 \%$ (2) Competence has significant effect on Audit Quality because it has a significance value lower than the level of significance of $5 \%$ that is equal to 0,024 or $2,4 \%$ (3) Independence has no significant effect on Audit Quality because it has a significance value greater than the level of significance of 5\% that is equal to 0,610 or $61 \%$ (4) Complexity of The Audit has no significant effect on Audit Quality because it has a significance value greater than the level of significance of $5 \%$ that is equal to 0,341 or $34,1 \%$.
\end{abstract}

Keywords: The Auditor's Professional Skepticism, Competence, Independence, Complexity of The Audit and Audit Quality

\section{PENDAhUluan}

\subsection{Latar Belakang}

Dalam sebuah instansi pemerintahan dibutuhkannya pengawasan terhadap penggunaan dana pemerintah yang dilakukan oleh Aparat Pengawasan Intern Pemerintah (APIP) yang sesuai dengan peraturan undang-undang. APIP merupakan suatu lembaga instansi pemerintah yang dibentuk dengan tugas melaksanakan pengawasan intern (audit intern) di lingkungan pemerintahan pusat/daerah yang terdiri dari; Badan Pengawasan Keuangan dan Pembangunan (BPKP), Inspektorat Jenderal Kementerian, Inspektorat/Unit Pengawasan Intern pada Kementerian Negara, Inspekorat Utama/Inspektorat Lembaga Pemerintahan Non Kementerian, Inspektorat Unit/Pengawasan Intern pada Kesekretariatan Lembaga Tinggi Negara dan Lembaga Negara, Inspektorat Provinsi/Kabupaten/Kota dan Unit Pengawasan Intern pada Badan Hukum Pemerintah lainnya sesuai dengan peraturan perundang-undang. Pengawasan intern (audit intern) harus melakukan suatu pendekatan yang sistematik dan teratur dalam instansi pemerintah untuk mengevaluasi, memberikan keyakinan yang memadai atas ketaatan, efesiensi dan efektivitas pengelolaan resiko, pengendalian dan tata kelola untuk mencapai tujuan suatu instansi pemerintah yang sesuai dengan peraturan perundangundang.

Berdasarkan Peraturan Menteri Negara Pendayaan Aparatur Negara Nomor: PER/05/M.PAN/03/2008, Pengawasan intern adalah seluruh proses kegiatan audit, reviu, pemantauan, evaluasi, dan kegiatan pengawasan lainnya berupa asistensi, sosialisasi dan konsultansi terhadap penyelenggaraan tugas dan fungsi organisasi dalam rangka memberikan keyakinan yang memadai 
bahwa kegiatan telah dilaksanakan sesuai dengan tolok ukur yang telah ditetapkan secara efektif dan efisien untuk kepentingan pimpinan dalam mewujudkan kepemerintahan yang baik.

Kinerja APIP baik di lembaga pemerintah pusat maupun pemerintah daerah dalam melakukan pengawasan, reviu, evaluasi dan pemantauan masih lemah sehingga kualitas audit yang dihasilkan juga masih rendah (kbr.id, 2017). Kualitas audit dapat ditemukan pada beberapa fenomena yang terjadi di Indonesia seperti kasus korupsi yang terjadi pada Kementerian Perhubungan terkait dengan perizinan dan pengadaan proyek-proyek di lingkungan Ditjen Perhubungan Laut tahun anggaran 20162017 (tribunnews.com, 2017). Hal ini disebabkan masih lemahnya sistem pengendalian internal pemerintah sehingga mudah terjadinya korupsi di Kementerian Perhubungan. Selain itu, Inspektorat Jenderal Kementerian Perhubungan juga tidak memiliki integritas dan tidak berkompeten dalam melakukan pengawasan dan pemeriksaan di Kementerian Perhubungan sehingga mengakibatkan menurunnya kinerja Inspektorat Jenderal Kementerian Perhubungan.

Selanjutnya, kasus terkait dengan kualitas audit di Indonesia seperti yang terjadi pada Kementerian Lingkungan Hidup dan Kehutanan yang mendapatkan opini wajar dengan pengecualian (WDP) dari Badan Pemeriksa Keuangan (BPK) pada tahun 2016 yang berarti laporan keuangan yang telah disajikan secara wajar namun masih terdapat sejumlah bagian tertentu yang tidak wajar tetapi ketidakwajaran tersebut tidak mempengaruhi kewajaran laporan keuangan secara keseluruhan (bpk.go.id, 2017). Dengan BPK memberikan opini WDP, berarti Kementerian Lingkungan Hidup dan Kehutanan masih ada kekurangan atau bagian tertentu yang tidak wajar yang seharusnya diketahui oleh Inspektorat Jenderal Kementerian Lingkungan Hidup dan Kehutanan (Itjen-MENLHK) dan memberikan rekomendasi atas kekurangan tersebut. Dalam hal ini, Itjen-MENLHK tidak berkompeten dan kurang berperan aktif dalam melakukan pengawasan dan pemeriksaan sehingga menurunnya kinerja Itjen-MENLHK. Dengan masih banyaknya kinerja APIP yang lemah khususnya di Inspektorat Jenderal dalam melakukan pengawasan dan pemeriksaan di lingkup Kementerian dapat menyebabkan kualitas hasil pemeriksaan yang dihasilkan juga menurun.

Selain berdasarkan fenomena diatas, terdapat fenomena lain yang terkait dengan kualitas audit pada Itjen-MENLHK seperti berdasarkan data statistik tahun 2015 Kementerian Lingkungan Hidup dan Kehutanan, kualitas audit Itjen-MENLHK masih lemah. Hal ini disebabkan karena masih banyak sisa temuan audit di Inspektorat I-IV dari hasil tindak lanjut audit kinerja pada Kementerian Lingkungan Hidup dan Kehutanan yang belum ditindak lanjuti.

Tabel 1. Data Tindak Lanjut Hasil Audit Kinerja Tahun 2015

\begin{tabular}{|c|c|c|c|c|c|c|c|c|}
\hline \multirow[t]{2}{*}{ No. } & \multirow[t]{2}{*}{ Inspektorat } & \multicolumn{2}{|c|}{ Hasil Audit } & \multicolumn{2}{|c|}{ Tindak Lanjut } & \multicolumn{2}{|c|}{ Sisa } & \multirow{2}{*}{$\begin{array}{c}\text { Keterangan } \\
\text { Kualitas } \\
\text { Audit }\end{array}$} \\
\hline & & Temuan & Rekom & Temuan & Rekom & Temuan & Rekom & \\
\hline 1. & Inspektorat I & 7.466 & 12.710 & 7.283 & 12.454 & 183 & 256 & Kurang Baik \\
\hline 2. & Inspektorat II & 5.764 & 10.685 & 5.637 & 10.525 & 127 & 160 & Kurang Baik \\
\hline 3. & Inspektorat III & 4.978 & 9.418 & 4.748 & 9.105 & 230 & 313 & Kurang Baik \\
\hline 4. & Inspektorat IV & 5.575 & 10.793 & 5.292 & 10.325 & 283 & 468 & Kurang Baik \\
\hline
\end{tabular}

Sumber: www.menlhk.go.id

Dari hasil pemeriksaan tindak lanjut diatas, masih ada sisa temuan yang belum ditindak lanjuti. Dengan masih adanya sisa temuan audit yang belum ditindak lanjuti berarti masih lemahnya kinerja auditor dalam melaksanakan rekomendasi yang ada. Terdapat sisa temuan audit dapat salah satunya diakibatkan oleh adanya sebuah tindak lanjut yang membutuhkan proses yang panjang seperti penetapan kawasan hutan. Dan juga masih lemahnya sistem pengendalian internal yang disebabkan Itjen-MENLHK kurang berperan aktif dalam melakukan pengawasan dan pemeriksaan terhadap kegiatan operasional Kementerian Lingkungan Hidup dan Kehutanan. Selain itu, auditor ItjenMENLHK juga memiliki keterbatasan waktu dalam melakukan pemeriksaan dan juga banyaknya tugas kepengawasan sehingga mengakibatkan kurangnya responsif terhadap hasil pemeriksaan. Dengan lemahnya kinerja auditor akan menurunkan kualitas audit yang dihasilkan. Menurut BPK, tindak lanjut menjadi indikator keberhasilan suatu pemeriksaan. Semakin cepat tindak lanjut diselesaikan menunjukkan semakin baik suatu sistem dijalankan sehingga pemeriksaan yang dihasilkan semakin baik. Pada Kementerian Lingkungan Hidup dan Kehutahan masih ada sisa temuan yang belum ditindak lanjut yang berarti pemeriksaan yang dihasilkan masih kurang baik. Oleh karena 
itu, perlu ditingkatkan lagi kinerja APIP setingkat inspektorat termasuk kementerian agar menghasilkan pemeriksaan yang berkualitas dengan menjaga independensi auditor pengawasan intern pemerintah dan harus profesional, objektif dan berkompeten dalam melakukan pemeriksaan dan pengawasan yang terintegrasi dalam kegiatan operasional dan mendokumentasikannya.

APIP dalam melakukan penugasannya harus dapat mempertimbangkan suatu informasi yang diterima dalam menilai atau memberikan evaluasi pada instansi pemerintah tersebut atas kegiatan operasional yang dilakukannya. Sehingga auditor harus menerapkan sikap skeptisisme dalam penugasaan auditnya terhadap bukti audit yang diterima. APIP juga harus memiliki kompetensi yang tinggi dalam melakukan pemeriksaan atau pengawasan agar dapat mendeteksi adanya kecurangan dalam suatu instansi pemerintah. Auditor harus mempunyai kemampuan, ahli dan berpengalaman dalam memahami kriteria dan dalam menentukan jumlah bahan bukti yang dibutuhkan untuk dapat mendukung kesimpulan yang akan diambilnya (Rahayu \& Suharyati, 2013, hlm. 2). Auditor harus memiliki kompetensi yang dibutuhkan untuk melaksanakan tanggung jawabnya. Dengan auditor memiliki kompetensi yang tinggi maka auditor dapat mengenali, meneliti dan menguji adanya indikasi kecurangan.

APIP juga harus memiliki independensi dalam melakukan penugasaan audit. Semakin tinggi independensi seorang auditor, maka kualitas audit yang akan dihasilkan akan semakin baik. Independensi meningkat jika fungsi auditor internal memiliki akses komunikasi yang memadai terhadap pimpinan dan dewan pengawas organisasi. Auditor harus memiliki sikap mental yang objektif, tidak memihak dan menghindari kemungkinan timbulnya pertentangan kepentingan (conflict of interest). APIP dalam melakukan penugasaannya akan mempunyai kompleksitas audit yang membuat seorang auditor kesulitan membuat keputusan.

\subsection{Perumusan Masalah}

Berdasarkan latar belakang yang telah dikemukkan diatas, masalah yang dapat diidentifikasi dalam penelitian ini adalah (1) Apakah Skeptisisme Profesional Auditor berpengaruh signifikan terhadap Kualitas Audit? (2) Apakah Kompetensi berpengaruh signifikan terhadap Kualitas Audit? (3) Apakah Independensi berpengaruh signifikan terhadap Kualitas Audit? (4) Apakah Kompleksitas Audit berpengaruh signifikan terhadap Kualitas Audit?

\section{TINJAUAN PUSTAKA DAN HIPOTESIS}

\subsection{Teori Keagenan}

Jensen \& Meckling (1976) menjelaskan hubungan agensi sebagai kontrak dimana satu atau lebih orang (principle) melibatkan orang lain (agen) untuk melakukan beberapa layanan atas nama mereka yang melibatkan pendelegasian beberapa wewenang dalam membuat keputusan kepada agen tersebut. Teori keagenan (agency theory) membahas tentang adanya hubungan kerja sama antara pihak (principal) yang mendelegasikan pekerjaan kepada pihak lain (agent) sebagai pihak yang melakukan pekerjaan (Rahmawati, 2012, hlm. 153).

Berdasarkan teori diatas, dapat disimpulkan bahwa teori keagenan dalam sebuah instansi pemerintah muncul ketika adanya hubungan antara agen yaitu auditor pada inspektorat jenderal dengan principal yaitu pengguna informasi laporan hasil pemeriksaan, dimana adanya benturan kepentingan antara kedua belah pihak mengenai informasi laporan hasil pemeriksaan dikarenakan prinsipal tidak memiliki informasi yang cukup tentang kinerja dalam bentuk tingkat kualitas audit yang dihasilkan oleh agen.

\subsection{Teori Atribusi}

Teori atribusi mempelajari proses bagaimana seseorang menginterprestasikan suatu peristiwa, alasan atau sebab perilakunya. Teori ini dikembangkan oleh Fritz Heider (1958) menjelaskan bahwa perilaku seseorang ditentukan oleh kombinasi antara kekuatan internal (internal forces) dan kekuatan eksternal (external forces). Kekuatan internal (internal forces), yaitu faktor-faktor yang berasal dari dalam diri seseorang seperti kemampuan atau usaha dan kekuatan eksternal (external forces), yaitu faktor-faktor yang berasal dari luar, seperti kesulitan dalam pekerjaan atau keberuntungan. Berdasarkan hal tersebut, seseorang akan termotivasi untuk memahami lingkungannya dan sebabsebab kejadian tertentu (Lubis, 2010, hlm. 90). 
Berdasarkan teori diatas, dapat disimpulkan bahwa teori atribusi merupakan perilaku individu disebabkan oleh dua faktor yaitu, faktor internal dan faktor eksternal. Faktor internal yaitu faktorfaktor yang berasal dari dalam diri seseorang dan faktor eksternal yaitu faktor-faktor yang berasal dari luar yang disebabkan oleh situasi. Dalam melaksanakan pengawasan dan pemeriksaaan di instansi pemerintah, perilaku APIP dipengaruhi oleh dua faktor yang berhubungan dengan perilaku individu atau auditor yaitu faktor internal terdiri dari kompetensi dan independensi dan faktor eksternal terdiri dari kompleksitas audit dan skeptisisme professional auditor sehingga mampu memahami kondisi lingkungannya untuk mencapai target kinerja dalam bentuk tingkat kualitas audit yang dihasilkan oleh auditor.

\subsection{Kualitas Audit}

Berdasarkan Peraturan BPK No.1 Tahun 2017, untuk menjaga kualitas audit maka pelaksanaan pemeriksaan perlu dilaksanakan berdasarkan suatu standar pemeriksaan. Dalam penyusunan laporan hasil pemeriksaan terdapat unsur-unsur laporan yaitu tepat waktu, lengkap, akurat, objektif, meyakinkan, jelas dan ringkas. Kualitas audit merupakan tingkat kemungkinan dimana seorang auditor menemukan serta melaporkan mengenai adanya suatu pelanggaran dalam sistem akuntansi (Hasbullah, dkk, 2014). Kualitas hasil pemeriksaan adalah kualitas kerja auditor yang ditunjukkan dengan laporan hasil pemeriksaan yang dapat diandalkan berdasarkan standar yang telah ditetapkan (Sukriah, dkk, 2009).

Berdasarkan definisi diatas, dapat disimpulkan bahwa kualitas audit merupakan kualitas hasil laporan pemeriksaan yang berdasarkan standar audit yang telah ditetapkan untuk menghindari kemungkinan terjadinya pelanggaran dalam sistem akuntansi. Kualitas audit menjadi hal penting dalam setiap audit untuk meningkatkan tingkat kepercayaan pemangku kepentingan atau pengguna laporan hasil pemeriksaan terhadap pemeriksaan yang dilakukan oleh auditor.

\subsection{Skeptisisme Profesional Auditor}

Menurut Asosiasi Auditor Intern Pemerintah Indonesia (AAIPI), Skeptisme profesional adalah sikap yang mencakup pikiran yang selalu mempertanyakan dan melakukan pengujian secara kritis bukti. Berdasarkan Peraturan Badan Pemeriksa Keuangan (BPK) Republik Indonesia No.1 Tahun 2017, Sikap skeptisisme profesional berarti pemeriksa membuat penilaian kritis dengan pikiran yang selalu mempertanyakan kecukupan dan ketepatan bukti yang diperoleh selama pemeriksaan. Skeptisisme profesional auditor adalah suatu sikap yang mencakup pikiran yang selalu mempertanyakan dan melakukan evaluasi secara kritis terhadap bukti audit. Kualitas hasil pemeriksaan akan meningkat dengan adanya peningkatan skeptisisme profesional auditor (Sudrajat, dkk, 2015).

Berdasarkan definisi diatas, dapat disimpulkan bahwa skeptisisme profesional merupakan sikap auditor yang selalu mempertanyakan atas bukti audit dan melakukan evaluasi secara kritis terhadap bukti audit untuk menyadari ada tidaknya salah saji dalam laporan keuangan. Auditor perlu menerapkan sikap skeptisime profesional dalam melakukan pemeriksaan terhadap bukti audit yang diterima. Keyakinan yang memadai atas bukti-bukti yang ditemukan akan sangat membantu auditor dalam melaksanakan proses audit agar kualitas audit dapat tercapai. Semakin tinggi auditor menerapkan sikap skeptisisme dalam proses audit maka semakin tinggi kualitas audit yang dihasilkan.

\subsection{Kompetensi}

Berdasarkan Peraturan BPK No.1 Tahun 2017, kompetensi adalah pendidikan, pengetahuan, pengalaman, dan/atau keahlian yang dimiliki seseorang, baik tentang pemeriksaan maupun tentang hal-hal atau bidang tertentu. Kompeten artinya auditor harus mempunyai kemampuan, ahli dan berpengalaman dalam memahami kriteria dan dalam menentukan jumlah bahan bukti yang dibutuhkan untuk dapat mendukung kesimpulan yang akan diambilnya (Rahayu \& Suharyati, 2013, hlm. 2). Kompetensi auditor adalah kualifkasi yang dibutuhkan oleh auditor untuk melaksanakan audit kinerja yang benar (Rai, 2008, hlm. 63).

Berdasarkan definisi diatas, dapat disimpulkan bahwa seorang auditor harus mempunyai pengetahuan, pengalaman dan keahlian khusus dalam melakukkan pemeriksaan sehingga dapat 
memahami kriteria dan menemukan bukti audit. Auditor yang berkompeten akan menghasilkan kualitas audit yang baik. Dengan auditor yang berkompeten dapat memahami. Semakin tinggi kompetensi auditor maka semakin tinggi kualitas audit yang akan dihasilkan.

\subsection{Independensi}

Independensi merupakan sikap mental yang dimiliki auditor untuk tidak memihak dalam melakukan audit (Rahayu \& Suharyati, 2013, hlm. 38). Independensi dalam audit berarti cara pandang yang tidak memihak di dalam pelaksanaan pengujian, evaluasi hasil pemeriksaan dan penyusunan laporan audit. Sikap mental independen tersebut harus meliputi independence in fact dan independence in appearance (Rahayu \& Suharyati, 2013, hlm. 51). Peraturan BPK No.1 Tahun 2017, independensi adalah suatu sikap dan tindakan dalam melaksanakan pemeriksaan untuk tidak memihak kepada siapapun dan tidak dipengaruhi oleh siapapun.

Berdasarkan definisi diatas, dapat disimpulkan bahwa independensi merupakan suatu sikap auditor yang tidak memihak kepada siapapun dalam melaksanakan pemeriksaan, evaluasi hasil pemeriksaan dan penyusunan laporan audit. Selama melaksanakan pemeriksaan auditor harus selalu menegakkan sikap independensi. Auditor harus jujur dalam melakukan pemeriksaan untuk mengungkapan fakta yang ada. Sikap independensi auditor perlu diterapkan dalam proses audit agar kualitas audit yang dihasilkan baik. Semakin tinggi independensi auditor maka semakin tinggi kualitas audit yang dihasilkan.

\subsection{Kompleksitas Audit}

Kompleksitas tugas dalam pengauditan dipengaruhi oleh faktor-faktor yaitu banyak informasi yang tidak relevan dalam artian informasi tersebut tidak konsisten dengan kejadian yang akan diprediksi, adanya ambiguitas yang tinggi yaitu beragamanya outcome yang diharapkan oleh klien dari kegiatan pengauditan (Anugerah \& Akbar, 2014). Kompleksitas tugas merupakan tingkat kesulitan tugas dan struktur tugas yang dihadapi oleh auditor (Hasbullah, dkk, 2014). Tingkat kekompleksitasan tugas tersebut tergantung dari banyaknya informasi mengenai tugas pemeriksaan atau audit serta bagaimana tingkat keakuratan informasi yang ada yang didapat auditor selama tugas pemeriksaan.

Berdasarkan definisi diatas, dapat disimpulkan bahwa kompleksitas audit merupakan persepsi individu mengenai kesulitan tugas auditor dalam melaksanakan pemeriksaan yang disebabkan adanya ambiguitas dan terbatasnya data ingat serta kemampuan yang dimiliki auditor sehingga dapat mempengaruhi hasil laporan pemeriksaan. Dengan tingginya kompleksitas selama proses audit, maka akan mempengaruhi kualitas audit. Semakin tinggi kompleksitas audit maka semakin buruk kualitas audit yang dihasilkan.

\subsection{Pengaruh Skeptisisme Profesional Auditor Terhadap Kualitas Audit}

Auditor dalam melakukan pemeriksaan harus menerapkan sikap skeptisisme professional terhadap bukti audit yang diterima. Berdasarkan Peraturan Badan Pemeriksa Keuangan (BPK) Republik Indonesia No.1 Tahun 2017, sikap skeptisisme profesional berarti pemeriksa membuat penilaian kritis dengan pikiran yang selalu mempertanyakan kecukupan dan ketepatan bukti yang diperoleh selama pemeriksaan. Sikap skeptisisme profesional merupakan faktor eksternal dalam teori atribusi karena termasuk perilaku yang disebabkan oleh situasi yang dihadapi auditor untuk menghasilkan kualitas audit yang baik. Dengan kualitas audit yang baik maka kebutuhan pengguna informasi dapat terpenuhi dan tidak adanya ketidakseimbangan informasi antara prinsipal dan agen seperti yang dinyatakan dalam teori agensi.

Penelitian yang dilakukan oleh Sudrajat, dkk (2015), Anugerah \& Akbar (2014), Afriyani, dkk (2014) dan Mufidah (2015) menunjukkan bahwa skeptisisme professional berpengaruh signifikan terhadap kualitas audit. Kualitas hasil pemeriksaan akan meningkat dengan adanya peningkatan skeptisisme profesional auditor (Sudrajat, dkk, 2015). Hal ini menunjukkan bahwa semakin tinggi skeptisisme professional seorang auditor maka akan semakin berkualitas hasil audit yang diberikan. Maka hipotesis yang diajukan dalam penelitian ini adalah

H1: Skeptisisme Profesional Auditor bepengaruh signifikan terhadap Kualitas Audit. 


\subsection{Pengaruh Kompetensi Terhadap Kualitas Audit}

Kompetensi auditor adalah kualifkasi yang dibutuhkan oleh auditor untuk melaksanakan audit kinerja yang benar. Dalam melakukan audit, seorang auditor harus memiliki mutu personal yang baik, pengetahuan yang memadai, serta keahlian khusus di bidangnya (Rai, 2008, hlm. 63). Kompetensi merupakan faktor internal dalam teori atribusi karena termasuk perilaku individu yang berasal dari dalam diri auditor maka dengan auditor yang berkompeten akan memberikan hasil audit yang berkualitas. Dengan kualitas audit yang baik maka kebutuhan pengguna informasi dapat terpenuhi dan tidak ada kesalahan informasi antara prinsipal dan agen seperti yang dinyatakan dalam teori agensi.

Penelitian yang dilakukan oleh Anugerah \& Akbar (2014), Usman (2016), Pratomo (2016), Saputra \& Susanto (2016), Mufidah (2015) dan Sukriah, dkk (2009) menunjukkan bahwa kompetensi berpengaruh signifikan terhadap kualitas audit. Auditor harus memiliki pengetahuan untuk memahami entitas yang diaudit dan kemampuan untuk bekerja sama dengan tim dalam menganalisa permasalahan. Semakin tinggi tingkat kompetensi yang dimiliki auditor, maka semakin meningkat kualitas audit yang dihasilkan (Sukriah, dkk, 2009). Maka hipotesis yang diajukan dalam penelitian ini adalah

\section{H2: Kompetensi berpengaruh signifikan terhadap Kualitas Audit.}

\subsection{Pengaruh Independensi Terhadap Kualitas Audit}

Independensi merupakan kebebasan posisi auditor baik dalam sikap maupun penampilan dalam hubungannya dengan pihak lain yang terkait dengan tugas audit yang dilaksanakannya (Sukriah, dkk, 2009). Selama melaksanakan pemeriksaan auditor harus selalu menegakkan sikap independensi agar dapat mengungkapan fakta yang terjadi tanpa memihak siapapun sehingga dapat menghasilkan kualitas audit yang baik. Independensi merupakan faktor internal dalam teori atribusi karena independensi termasuk perilaku individu yang berasal dari dalam diri sehingga akan mempengaruhi hasil pemeriksaan atas pengujian maupun evaluasi. Auditor menegakkan sikap independensinya selama proses audit akan menghasilkan kualitas audit yang baik. Dengan kualitas audit yang baik maka kebutuhan pengguna informasi dapat terpenuhi sehingga tidak ada ketidakseimbangan informasi antara agen dan principal yang dinyatakan dalam teori agensi.

Penelitian yang dilakukan oleh Usman, dkk (2014), Zamzami, dkk (2017), Faizah \& Zuhdi (2013) dan Saputra \& Susanto (2016) menunjukkan bahwa independensi berpengaruh signifikan terhadap kualitas audit. Semakin independen seorang pemeriksa, maka semakin baik kualitas pemeriksaan yang dilakukan (Faizah \& Zuhdi, 2013). Maka hipotesis yang diajukan dalam penelitian ini adalah

\section{H3: Independensi berpengaruh signifikan terhadap Kualitas Audit}

\subsection{Pengaruh Kompleksitas Audit Terhadap Kualitas Audit}

Kompleksitas audit adalah persepsi auditor tentang kesulitan suatu tugas audit yang disebabkan oleh terbatasnya kapabilitas dan daya inget serta kemampuan untuk mengintegrasikan masalah yang dimiliki oleh seorang auditor (Sudrajat, dkk, 2015). Kompleksitas tugas merupakan tingkat kesulitan tugas dan struktur tugas yang dihadapi oleh auditor (Hasbullah, dkk, 2014). Tingkat kekompleksitasan audit tergantung terhadap banyaknya informasi selama pemeriksaan dan tingkat keakrutan informasi tersebut. Kompleksitas audit merupakan faktor eksternal dalam teori atribusi karena kompleksitas audit termasuk perilaku individu yang disebabkan oleh situasi yang dihadapi auditor sehingga akan mempengaruhi hasil pemeriksaan auditor. Dengan adanya kompleksitas audit maka auditor harus melaksanakan tugas dengan baik dan menghasilkan audit yang berkualitas. Sehingga kebutuhan pengguna informasi dapat terpenuhi dan tidak ada kesalahan informasi antara agen dan prinsipal yang dinyatakan dalam teori agensi.

Penelitian yang dilakukan oleh Sudrajat, dkk (2015) dan Hasbullah, dkk (2014) menunjukkan bahwa kompleksitas tugas berpengaruh signifikan terhadap kualitas audit. Semakin tinggi kompleksitas audit maka akan semakin tinggi kemampuan pemeriksa dalam menghasilkan kualitas audit (Sudrajat, dkk, 2015). Tingkat kekompleksitasan tugas auditor tergantung dari banyaknya informasi tentang tugas dan tingkat keakuratan informasi yang ada. Maka hipotesis yang diajukan dalam penelitian ini adalah

H4: Kompleksitas Audit berpengaruh signifikan terhadap Kualitas Audit 


\section{METODE PENELITIAN}

\subsection{Pengukuran dan Definisi Operasional Variabel Variabel Dependen (Y)}

Kualitas Audit adalah kualitas kerja auditor yang ditunjukkan dengan laporan hasil pemeriksaan yang dapat diandalkan berdasarkan standar yang telah ditetapkan (Sukriah, dkk, 2009).

Variabel ini diukur dengan menggunakan item penyataan yang diadopsi dari (Sukriah, dkk, aaa2009) dengan menggunakan indikator kesesuaian pemeriksaan dengan standar audit dan kualitas laporan hasil pemeriksaan. Penelitian ini menggunakan skala 5 point.

\section{Variabel Independen (X)}

a. Skeptisisme Profesional Auditor (X1)

Peraturan Badan Pemeriksa Keuangan (BPK) Republik Indonesia No.1 Tahun 2017, Sikap skeptisisme profesional berarti pemeriksa membuat penilaian kritis dengan pikiran yang selalu mempertanyakan kecukupan dan ketepatan bukti yang diperoleh selama pemeriksaan.

Variabel ini diukur dengan menggunakan item pertanyaan yang diadopsi dari (Sudrajat, dkk, 2015) dengan menggunakan indikator melaksanakan tugas dengan sikap tekun dan hati-hati, tidak mudah percaya dengan bukti audit, mempertanyakan dan mengevaluasi bukti audit, dan mengumpulkan bukti audit yang detail dan cukup. Penelitian ini menggunakan skala 5 point.

b. Kompetensi (X2)

Kompetensi auditor adalah kualifkasi yang dibutuhkan oleh auditor untuk melaksanakan audit kinerja yang benar. Dalam melakukan audit, seorang auditor harus memiliki mutu personal yang baik, pengetahuan yang memadai, serta keahlian khusus di bidangnya (Rai, 2008, hlm. 63).

Variabel ini diukur dengan menggunakan item pertanyaan yang diadopsi dari (Sukriah, dkk, 2009) dengan menggunakan indikator mutu personal, pengetahuan umum dan keahlian khusus. Penelitian ini menggunakan skala 5 point.

c. Independensi (X3)

Peraturan BPK No.1 Tahun 2017, independensi adalah suatu sikap dan tindakan dalam melaksanakan pemeriksaan untuk tidak memihak kepada siapapun dan tidak dipengaruhi oleh siapapun.

Variabel ini diukur dengan menggunakan item pertanyaan yang diadopsi dari (Sukriah, dkk, 2009) dengan menggunakan indikator independensi penyusunan program, independensi pelaksanaan penyusunan dan independensi pelaporan. Penelitian ini menggunakan skala 5 point.

d. Kompleksitas Audit (X4)

Kompleksitas audit adalah persepsi auditor tentang kesulitan suatu tugas audit yang disebabkan oleh terbatasnya kapabilitas dan daya inget serta kemampuan untuk mengintegrasikan masalah yang dimiliki oleh seorang auditor (Sudrajat, dkk, 2015).

Variabel ini diukur dengan menggunakan item pertanyaan yang diadopsi dari (Sudrajat, dkk, 2015) dengan menggunakan indikator kesulitan tugas dan struktur tugas. Penelitian ini menggunakan skala 5 point.

\subsection{Populasi dan Sampel}

Populasi yang digunakan dalam penelitian ini adalah auditor Inspektorat Jenderal Kementerian Lingkungan Hidup dan Kehutanan. Pengambilan sampel menggunakan purposive sampling yaitu auditor Inspektorat Wilayah I-IV di Inspektorat Jenderal Kementerian Lingkungan Hidup dan Kehutanan, auditor yang memiliki pengalaman kerja minimal 2 tahun dan auditor yang tingkat pendidikannya minimal S1.

\subsection{Jenis dan Sumber Data}

Data yang digunakan dalam penelitian ini merupakan data primer. Data primer dalam penelitian ini diperoleh melalui kuesioner berupa 41 pertanyaan yang terstruktur dan dibagikan secara langsung kepada auditor Inspektorat Jenderal Kementerian Lingkungan Hidup dan Kehutanan.

\section{HASIL DAN PEMBAHASAN}

EQUITY : Jurnal Ekonomi, Manajemen, Akuntansi | Vol. 21 No.2 
Tabel 2. Daftar Kuesioner yang Di Sebar dan Di Terima

\begin{tabular}{lcccc}
\hline $\begin{array}{c}\text { Inspektorat Jenderal } \\
\text { Kementerian } \\
\text { Lingkungan Hidup }\end{array}$ & Didistribusikan & Tidak Kembali & $\begin{array}{c}\text { Tidak Memenuhi } \\
\text { Kriteria }\end{array}$ & Diolah \\
\hline Inspektorat Wilayah I & 15 & 3 & 1 & 11 \\
\hline Inspektorat Wilayah II & 25 & - & 5 & 20 \\
\hline Inspektorat Wilayah III & 15 & 3 & - & 12 \\
\hline Inspektorat Wilayah IV & 15 & - & 1 & 14 \\
\hline Total & $\mathbf{7 0}$ & $\mathbf{6}$ & $\mathbf{7}$ & $\mathbf{5 7}$ \\
\hline Sumb
\end{tabular}

Sumber: Data primer, diolah

Berdasarkan tabel 14 dari kuesioner yang disebar, yaitu 70 kuesioner. Jumlah kuesioner yang diisi dan dikembalikan sebanyak 64 kuesioner dari auditor yang bekerja di Inspektorat Jenderal Kementerian Lingkungan Hidup dan Kehutanan. Jumlah kuesioner yang tidak dapat diolah sebanyak 7 kuesioner karena tidak sesuai dengan kriteria. Sehingga kuesioner yang digunakan dalam penelitian ini sebanyak 57 kuesioner dari auditor yang bekerja di Inspektorat Jenderal Kementerian Lingkungan Hidup dan Kehutanan

\subsection{Uji Kualitas Data}

\subsubsection{Uji Validitas}

Tabel 3. Hasil Uji Validitas

\begin{tabular}{|c|c|c|c|}
\hline Variabel & $\begin{array}{c}\text { Pearson } \\
\text { Correlation }\end{array}$ & $\mathrm{r}$ tabel & Keterangan \\
\hline \multicolumn{4}{|l|}{ Kualitas Audit } \\
\hline KA1 & 0,740 & 0,2609 & VALID \\
\hline KA2 & 0,734 & 0,2609 & VALID \\
\hline KA3 & 0,708 & 0,2609 & VALID \\
\hline KA4 & 0,709 & 0,2609 & VALID \\
\hline KA5 & 0,626 & 0,2609 & VALID \\
\hline KA6 & 0,834 & 0,2609 & VALID \\
\hline KA7 & 0,686 & 0,2609 & VALID \\
\hline KA8 & 0,659 & 0,2609 & VALID \\
\hline KA9 & 0,786 & 0,2609 & VALID \\
\hline KA10 & 0,787 & 0,2609 & VALID \\
\hline \multicolumn{4}{|c|}{ Skeptisisme Profesional Auditor } \\
\hline S1 & 0,712 & 0,2609 & VALID \\
\hline S2 & 0,760 & 0,2609 & VALID \\
\hline S3 & 0,798 & 0,2609 & VALID \\
\hline S4 & 0,774 & 0,2609 & VALID \\
\hline S5 & 0,847 & 0,2609 & VALID \\
\hline S6 & 0,758 & 0,2609 & VALID \\
\hline \multicolumn{4}{|l|}{ Kompetensi } \\
\hline $\mathrm{K} 1$ & 0,638 & 0,2609 & VALID \\
\hline $\mathrm{K} 2$ & 0,595 & 0,2609 & VALID \\
\hline K3 & 0,683 & 0,2609 & VALID \\
\hline K4 & 0,717 & 0,2609 & VALID \\
\hline K5 & 0,797 & 0,2609 & VALID \\
\hline K6 & 0,704 & 0,2609 & VALID \\
\hline K7 & 0,675 & 0,2609 & VALID \\
\hline K8 & 0,749 & 0,2609 & VALID \\
\hline K9 & 0,618 & 0,2609 & VALID \\
\hline K10 & 0,732 & 0,2609 & VALID \\
\hline Independensi & & & \\
\hline
\end{tabular}




\begin{tabular}{cccc}
\hline I1 & 0,766 & 0,2609 & VALID \\
\hline I2 & 0,763 & 0,2609 & VALID \\
\hline I3 & 0,857 & 0,2609 & VALID \\
\hline I4 & 0,873 & 0,2609 & VALID \\
\hline I5 & 0,624 & 0,2609 & VALID \\
\hline I6 & 0,704 & 0,2609 & VALID \\
\hline I7 & 0,772 & 0,2609 & VALID \\
\hline I8 & 0,645 & 0,2609 & VALID \\
\hline I9 & 0,769 & 0,2609 & VALID \\
\hline Kompleksitas Audit & & & \\
\hline KT1 & 0,510 & 0,2609 & VALID \\
\hline KT2 & 0,758 & 0,2609 & VALID \\
\hline KT3 & 0,739 & 0,2609 & VALID \\
\hline KT4 & 0,561 & 0,2609 & VALID \\
\hline KT5 & 0,789 & 0,2609 & VALID \\
\hline KT6 & 0,758 & 0,2609 & VALID \\
\hline
\end{tabular}

Sumber: Data Diolah, SPSS 23

Tingkat signifikansi dalam penelitian ini adalah $0,05(\mathrm{a}=5 \%)$ dari 57 responden. Pengujian validitas dilakukan dengan membandingan nilai $r$ hitung dengan $r$ tabel, dimana $\mathrm{df}=\mathrm{n}-2=55$, maka angka kritis $r$ tabel yang didapat adalah sebesar 0,2609. Sehingga hasil menunjukan bahwa semua indikator memiliki nilai pearson correlation yang lebih besar dari nilai $r$ tabel $>0,2542$ sehingga mengartikan bahwa semua pernyataan tersebut adalah valid.

\subsubsection{Uji Reliabilitas}

Uji reliabilitas dilakukan dengan dasar pengambilan keputusan jika nilai cronbach alpha melebihi 0,70 maka pernyataan variabel tersebut reliabel dan sebaliknya.

Tabel 4. Hasil Uji Reliabilitas

\begin{tabular}{cccc}
\hline Variabel & $\begin{array}{c}\text { Cronbach's } \\
\text { Alpha }\end{array}$ & $\begin{array}{c}\text { Standard } \\
\text { Alpha }\end{array}$ & Kesimpulan \\
\hline Kualitas Audit & 0,895 & 0,70 & RELIABEL \\
\hline $\begin{array}{c}\text { Skeptisisme Profesional } \\
\text { Auditor }\end{array}$ & 0,863 & 0,70 & RELIABEL \\
\hline Kompetensi & 0,871 & 0,70 & RELIABEL \\
\hline Independensi & 0,899 & 0,70 & RELIABEL \\
\hline Kompleksitas Audit & 0,743 & 0,70 & RELIABEL \\
\hline
\end{tabular}

Sumber: Data Diolah, SPSS 23

\subsubsection{Analisis Statistik dan Deskritif Data}

Tabel 5. Hasil Statistik Deskriptif

Descriptive Statistics

\begin{tabular}{lccccc}
\hline & $\mathrm{n}$ & Minimum & Maximum & Mean & $\begin{array}{c}\text { Std. } \\
\text { Deviation }\end{array}$ \\
\hline Kualitas Audit & 57 & 30 & 50 & 43,91 & 4,537 \\
\hline $\begin{array}{l}\text { Skeptisisme } \\
\text { Profesional Auditor }\end{array}$ & 57 & 18 & 30 & 25,63 & 2,736 \\
\hline Kompetensi & 57 & 30 & 50 & 42,61 & 4,651 \\
\hline Independensi & 57 & 21 & 45 & 36,07 & 5,331 \\
\hline Kompleksitas Audit & 57 & 15 & 26 & 21,47 & 2,713 \\
\hline
\end{tabular}

Valid n (listwise) 57

Sumber: Data Diolah, SPSS 23 
Berdasarkan tabel 23 menunjukkan bahwa jumlah data penelitian (n) adalah sebanyak 57. Variabel Kualitas Audit memiliki nilai minimum sebesar 30 dan nilai maksimum sebesar 50. Nilai rata-rata variabel Kualitas Audit adalah sebesar 43,91 dengan nilai standar deviasi sebesar 4,537. Nilai standar deviasi yang lebih kecil dari nilai rata-rata dapat diartikan bahwa tidak adanya kesenjangan yang cukup besar pada karakteristik personal responden, hal ini menunjukkan bahwa semakin kecil nilai standar deviasi menunjukkan semakin dekat nilai data sampel dengan rata-rata yang artinya data cukup baik.

Variabel Skeptisisme Profesional Auditor memiliki nilai minimum sebesar 18 dan nilai maksimum sebesar 30. Nilai rata-rata variabel Skeptisisme Profesional Auditor adalah sebesar 25,63 dengan nilai standar deviasi sebesar 2,736. Nilai standar deviasi yang lebih kecil dari nilai rata-rata dapat diartikan bahwa tidak adanya kesenjangan yang cukup besar pada karakteristik personal responden, hal ini menunjukkan bahwa semakin kecil nilai standar deviasi menunjukkan semakin dekat nilai data sampel dengan rata-rata yang artinya data cukup baik.

Variabel Kompetensi memiliki nilai minimum sebesar 30 dan nilai maksimum sebesar 50 Nilai rata-rata variabel Kompetensi adalah sebesar 42,61 dengan nilai standar deviasi sebesar 4,651. Nilai standar deviasi yang lebih kecil dari nilai rata-rata dapat diartikan bahwa tidak adanya kesenjangan yang cukup besar pada karakteristik personal responden, hal ini menunjukkan bahwa semakin kecil nilai standar deviasi menunjukkan semakin dekat nilai data sampel dengan rata-rata yang artinya data cukup baik.

Variabel Independensi memiliki nilai minimum sebesar 21 dan nilai maksimum sebesar 45. Nilai rata-rata variabel Independensi adalah sebesar 36,07 dengan nilai standar deviasi sebesar 5,331. Nilai standar deviasi yang lebih kecil dari nilai rata-rata dapat diartikan bahwa tidak adanya kesenjangan yang cukup besar pada karakteristik personal responden, hal ini menunjukkan bahwa semakin kecil nilai standar deviasi menunjukkan semakin dekat nilai data sampel dengan rata-rata yang artinya data cukup baik.

Variabel Kompleksitas Audit memiliki nilai minimum sebesar 15 dan nilai maksimum sebesar kompleksitas audit adalah 26. Nilai rata-rata variabel Kompleksitas Audit adalah sebesar 21,47 dengan nilai standar deviasi menunjukkan nilai 2,713. Nilai standar deviasi yang lebih kecil dari nilai rata-rata dapat diartikan bahwa tidak adanya kesenjangan yang cukup besar pada karakteristik personal responden, hal ini menunjukkan bahwa semakin kecil nilai standar deviasi menunjukkan semakin dekat nilai data sampel dengan rata-rata yang artinya data cukup baik.

\subsection{Uji Asumsi Klasik}

\subsubsection{Normalitas}

Uji normalitas dalam penelitian ini menggunakan tiga pengujian, yaitu uji histogram, uji grafik P-Plot dan uji non-parametik Kormogorov-Smirnov (K-S). Hasil uji normalitas dengan menggunakan analisis Histogram ditunjukkan dengan grafik sebagai berikut:

Gambar 1. Hasil Uji Normalitas dengan Histogram

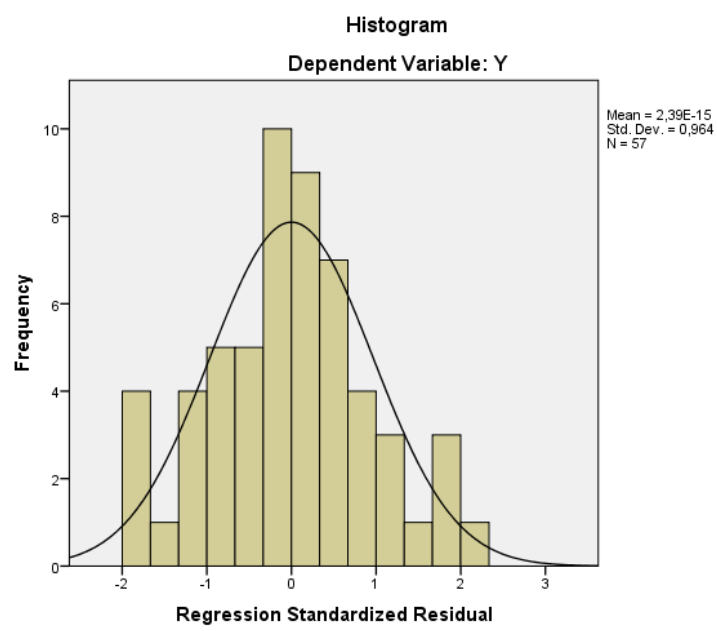

Sumber: Data Diolah, SPSS 23 
Berdasarkan gambar 1 menunjukkan bahwa bentuk kurva mengikuti bentuk lonceng sempurna, tidak miring ke kanan ataupun ke kiri. Dengan demikian, dapat disimpulkan bahwa data yang digunakan dalam penelitian ini memiliki distribusi norma sehingga model regresi memenuhi asumsi klasik normalitas. Artinya, model regresi, variabel pengganggu atau variabel residual memiliki distribusi normal. Hasil uji normalitas dengan uji P-Plot ditunjukkan dengan hasil uji grafik P-Plot disajikan sebagai berikut:

Gambar 2. Hasil Uji Normalitas dengan Grafik P-Plot

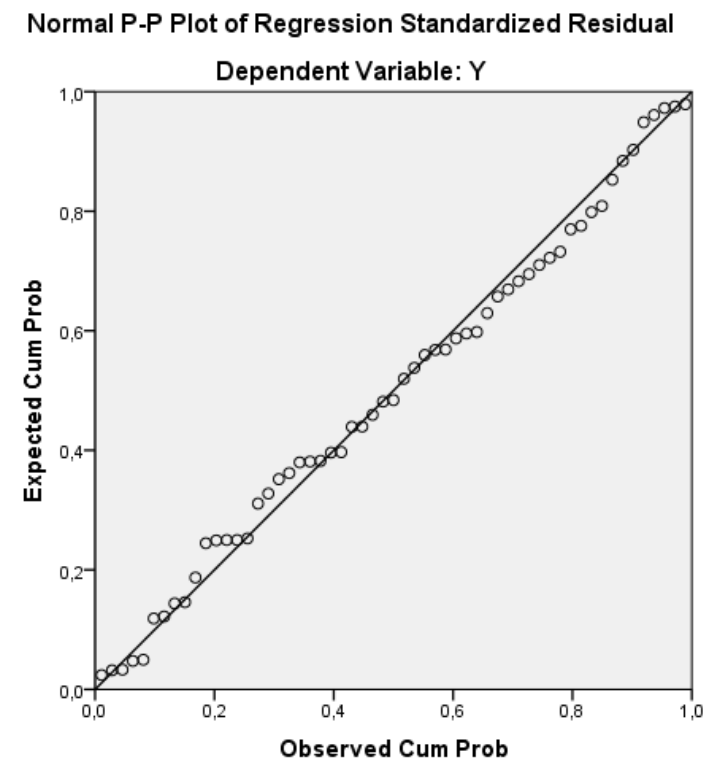

Sumber: Data Diolah, SPSS 23

Berdasarkan gambar 2, menunjukkan bahwa titik-titik tersebur menyebar mengikuti arah garis diagonal. Dengan demikian, dapat disimpulkan bahwa data yang digunakan dalam penelitian ini memiliki distribusi normal sehingga model regresi memenuhi asumsi klasik normalitas. Artinya, model regresi, variabel penggangu atau variabel residual memilki distribusi normal.

Hasil uji normalitas dengan uji One Sample Kolmogorov-Smirnov menunjukkan bahwa seluruh variabel sudah berdistribusi secara normal yang ditunjukkan dari nilai asymp.sig (2-tailed) dengan nilai sebesar $0,200>0,05$. Dapat disimpulkan bahwa data yang digunakan dalam penelitian ini memiliki distribusi normal. Artinya, model regresi, variabel penggangu atau variabel residual memiliki distribusi normal. Dapat digambarkan pada tabel dibawah ini:

Tabel 6. Hasil Uji Kolmogorov-Smirnov One-Sample Kolmogorov-Smirnov Test

\begin{tabular}{lr}
\hline & $\begin{array}{c}\text { Unstandardized } \\
\text { Residual }\end{array}$ \\
\hline $\mathrm{N}$ & 57 \\
\hline Test Statistic &, 061 \\
\hline Asymp. Sig. (2-tailed) &, $200^{\text {c,d }}$
\end{tabular}

Sumber: Data diolah, SPSS 23 


\subsubsection{Multikolonieritas}

Uji multikolonieritas bertujuan untuk mengetahui apakah antar variabel independen memiliki kolerasi atau tidak.

Tabel 7. Hasil Uji Multikolonieritas

\begin{tabular}{llll}
\multirow{2}{*}{ Model } & & \multicolumn{2}{c}{ Collinearity Statistics } \\
\cline { 3 - 4 } & & Tolerance & VIF \\
\hline \multirow{2}{*}{1} & (Constant) & & \\
\cline { 2 - 4 } & Skeptisisme Profesional Auditor &, 413 & 2,422 \\
\cline { 2 - 4 } & Kompetensi &, 535 & 1,868 \\
\cline { 2 - 4 } & Independensi &, 624 & 1,601 \\
\cline { 2 - 4 } & Kompleksitas Audit &, 865 & 1,156
\end{tabular}

Sumber: Data diolah, SPSS 23

Berdasarkan tabel, hasil menunjukkan bahwa variabel skeptisisme profesional auditor, kompetensi, independensi dan kompleksitas audit memiliki nilai tolerance $>0,10$ dan memiliki nilai $\mathrm{VIF}<10$, maka dapat disimpulkan data tidak terkena masalah multikolonieritas.

\subsubsection{Heteroskedastisitas}

Uji heteroskedastisitas digunakan untuk mengetahui apakah dalam model regresi terjadi ketidaksamaan variance pada residual dari satu pengamatan ke pengamatan lain. Pengujian heteroskedastisitas dalam penelitian ini dilihat berdasarkan titik-titik dalam grafik scatterplots dan juga berdasarkan uji glejser. Hasil uji heteroskedastisitas dengan grafik scatterplots sebagai berikut:

Gambar 3. Hasil Uji Heteroskedastisitas dengan Grafik Scatterplots

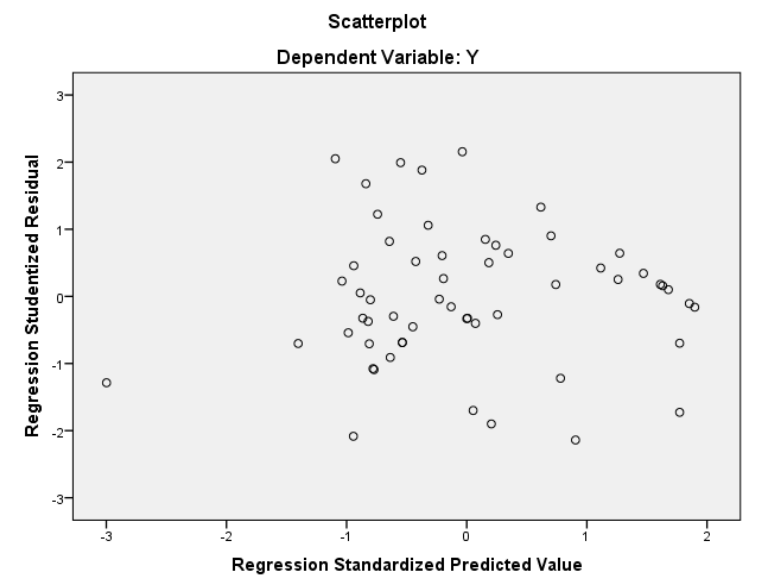

Sumber: Data Diolah, SPSS 23

Berdasarkan gambar 5 diatas, menunjukkan bahwa titik-titik tidak membentuk pola tertentu dan menyebar diatas dan dibawah angka 0 pada sumbu Y. Dengan demikian, dapat disimpulkan bahwa model regresi tidak terjadi heteroskedastisitas. Hasil uji heteroskedastisitas dengan uji glejser sebagai berikut:

Tabel 8. Hasil Uji Heteroskedastisitas dengan Uji Glejser Coefficients $^{\mathrm{a}}$

\begin{tabular}{lll} 
Model & & Sig. \\
\hline 1 & (Constant) &, 050 \\
\hline & Skeptisisme Profesional Auditor &, 626 \\
\hline & Kompetensi &, 744 \\
\hline & Independensi &, 519 \\
\hline & Kompleksitas Audit &, 696
\end{tabular}

a. Dependent Variable: ABSRES

Sumber: Data diolah, SPSS 23 
Berdasarkan tabel diatas, menunjukkan bahwa nilai probabilitas signifikasi variabel skeptisisme profesional auditor, kompetensi, independensi dan kompleksitas audit $>$ tingkat signifikansi 5\%. Dapat disimpulkan model regresi tidak mengandung adanya heteroskedastisitas.

\subsection{Uji Hipotesis}

\subsubsection{Uji Koefisien Determinasi $\left(\mathbf{R}^{2}\right)$}

Uji koefisien determinasi $\left(\mathrm{R}^{2}\right)$ dilakukan untuk mengukur seberapa besar peranan variabel independen yaitu skeptisisme profesional auditor, kompetensi, independensi dan kompleksitas audit secara simultan mempengaruhi perubahan yang terjadi pada variabel dependen yaitu kualitas audit.

Tabel 9. Hasil Uji Koefisien Determinasi $\left(\mathrm{R}^{2}\right)$

$$
\text { Model Adjusted R Square }
$$

1

Sumber: Data diolah, SPSS 23

Berdasarkan tabel hasil uji koefisien determinasi $\left(\mathrm{R}^{2}\right)$, dilihat dari Adjusted $R$ Square dapat diketahui bahwa variabel independen yaitu skeptisisme profesional auditor, kompetensi, independensi dan kompleksitas audit mampu menjelaskan variabel dependen yaitu kualitas audit sebesar 0,547 atau $54,7 \%$. Sedangkan sisanya sebesar $45,3 \%$ dipengaruhi oleh faktor-faktor lain yang tidak digunakan dalam penelitian ini.

\subsubsection{Uji Statistik t}

Uji statistik t dilakukan untuk mengetahui apakah variabel independen yaitu skeptisisme profesional auditor, kompetensi, independensi dan kompleksitas audit yang digunakan secara individual berpengaruh terhadap variabel dependen yaitu kualitas audit.

Tabel 10. Hasil Uji Statistik t

Coefficients $^{\mathrm{a}}$

\begin{tabular}{llcc} 
Model & & $\mathrm{t}$ & Sig. \\
\hline 1 & (Constant) & 1,568 &, 123 \\
\hline & Skeptisisme Profesional Auditor & 3,309 &, 002 \\
\hline & Kompetensi & 2,319 &, 024 \\
\hline & Independensi &, 514 &, 610 \\
\hline & Kompleksitas Audit &, 962 &, 341
\end{tabular}

Sumber: Data diolah, SPSS 23

Untuk mencari nilai $t_{\text {tabel }}$ dengan jumlah data penelitian (n) 57, jumlah variabel independen (k) 4 , nilai signifikansi 0,05 dan derajat kebebasan $(\mathrm{df}=\mathrm{n}-\mathrm{k}-1)$ 57-4-1= 52 adalah 2,00665 dengan tingkat signifikansi 5\%. Hasil uji statistik t pada tabel, menunjukkan bahwa variabel skeptisisme profesional auditor memiliki $t_{\text {hitung }}$ sebesar 3,309 dan $t_{\text {tabel }}$ sebesar 2,00665. Dapat disimpulkan bahwa $t_{\text {hitung }} 3,309>$ $\mathrm{t}_{\text {tabel }} 2,00665$ dengan tingkat signifikansi $0,002<0,05$, maka variabel independen skeptisisme profesional auditor secara parsial berpengaruh signifikan terhadap kualitas audit.

Hasil uji statistik t pada tabel, menunjukkan bahwa variabel kompetensi memiliki $t_{\text {hitung }}$ sebesar 2,319 dan $t_{\text {tabel }}$ sebesar 2,00665. Dapat disimpulkan bahwa $t_{\text {hitung }} 2,319>t_{\text {tabel }} 2,00665$ dengan tingkat signifikansi $0,024<0,05$, maka variabel independen kompetensi secara parsial berpengaruh signifikan terhadap kualitas audit.

Hasil uji statistik t pada tabel, menunjukkan bahwa variabel independensi memiliki $t_{\text {hitung }}$ sebesar 0,514 dan $t_{\text {tabel }}$ sebesar 2,00665. Dapat disimpulkan bahwa $t_{\text {hitung }} 0,514<\mathrm{t}_{\text {tabel }} 2,00665$ dengan tingkat signifikansi $0,610>0,05$, maka variabel independen independensi secara parsial tidak berpengaruh signifikan terhadap kualitas audit. 
Hasil uji statistik t pada tabel, menunjukkan bahwa variabel kompleksitas audit memiliki $\mathrm{t}_{\text {hitung }}$ sebesar 0,962 dan $t_{\text {tabel }}$ sebesar 2,00665. Dapat disimpulkan bahwa $t_{\text {hitung }} 0,962<t_{\text {tabel }} 2,00665$ dengan tingkat signifikansi 0,341 >0,05, maka variabel independen kompleksitas audit secara parsial tidak berpengaruh signifikan terhadap kualitas audit.

\subsubsection{Model Regresi Linear Berganda}

Model regresi linear berganda dalam penelitian ini digunakan untuk mengetahui bentuk pengaruh antara variabel Skeptisisme Profesional Auditor (S), Kompetensi (K), Independensi (I) dan Kompleksitas Audit (KT) terhadap Kualitas Audit (KA).

Tabel 11. Model Regresi Berganda

\begin{tabular}{llccc}
\multirow{2}{*}{ Model } & & \multicolumn{2}{c}{$\begin{array}{c}\text { Unstandardized } \\
\text { Coefficients }\end{array}$} & $\begin{array}{c}\text { Standardized } \\
\text { Coefficients }\end{array}$ \\
\cline { 3 - 5 } & & B & Std. Error & Beta \\
\hline 1 & (Constant) & 7,255 & 4,626 & \\
\cline { 2 - 5 } & $\begin{array}{l}\text { Skeptisisme Profesional } \\
\text { Auditor }\end{array}$ &, 768 &, 232 &, 463 \\
\cline { 2 - 5 } & Kompetensi &, 278 &, 120 &, 285 \\
\cline { 2 - 5 } & Independensi &, 050 &, 097 &, 058 \\
\cline { 2 - 5 } & Kompleksitas Audit &, 155 &, 162 &, 093
\end{tabular}

a. Dependent Variable: Kualitas Audit

Sumber: Data diolah, SPSS 23

Berdasarkan tabel, diperoleh persamaan model regresi sebagai berikut: $\mathrm{KA}=7,255+0,768 \mathrm{~S}+0,278 \mathrm{~K}+0,050 \mathrm{I}+0,155 \mathrm{KT}$

\subsection{Pembahasan}

\subsubsection{Pengaruh Skeptisisme Profesional Auditor Terhadap Kualitas Audit}

Pengujian terhadap hipotesis pertama dalam penelitian ini adalah untuk menguji apakah skeptisisme profesional auditor berpengaruh signifikan terhadap kualitas audit. Setelah dilakukan uji statistik t, hasil menunjukkan bahwa skeptisisme profesional auditor memiliki nilai signifikansi 0,002 dan nilai $t_{\text {hitung }}$ skeptisisme profesional auditor sebesar 3,309 dan $t_{\text {tabel }}$ sebesar 2,00665. Dapat disimpulkan bahwa $t_{\text {hitung }} 3,309>t_{\text {tabel }} 2,00665$ dengan tingkat signifikansi $0,002<0,05$, maka variabel independen skeptisisme profesional auditor secara parsial berpengaruh signifikan terhadap kualitas audit. Dengan demikian, $\mathrm{H}_{\mathrm{A}}$ diterima, maka dapat disimpulkan bahwa variabel skeptisisme profesional auditor berpengaruh signifikan terhadap kualitas audit. Hal ini menunjukkan bahwa sikap skeptisisme profesional auditor sangat penting dalam melakukan pemeriksaan untuk mendapatkan informasiinformasi atau bukti audit yang benar sehingga dapat meningkatkan kualitas hasil pemeriksaan dengan memberikan kesimpulan yang sebenar-benarnya. Dengan auditor selalu mempertanyakan dan mengevaluasi atas bukti audit yang diterima dari auditee sehingga auditor dapat memberikan opini atau kesimpulan dengan tepat terhadap pemeriksaan yang telah dilakukan auditor.

Hasil penelitian ini sejalan dengan penelitian yang dilakukan oleh Anugerah \& Akbar (2014), Sudrajat, dkk (2015), Mufidah (2015) dan Afriyani, dkk (2014) yang menyatakan bahwa skeptisisme profesional auditor berpengaruh signifikan terhadap kualitas audit. Sikap skeptisisme profesional auditor penting dalam melakukan penugasan audit untuk selalu mempertanyakan dan melakukan evaluasi secara kritis terhadap bukti audit yang diterima. Dengan auditor menerapkan sikap skeptisisme profesional dapat meningkatkan hasil audit yang berkualitas. Maka dapat disimpulkan skeptisisme profesional auditor berpengaruh signifikan terhadap kualitas audit. Namun penelitian ini tidak sejalan dengan penelitian yang dilakukan oleh Faizah \& Zuhdi (2013) yang menyatakan variabel skeptisisme profesional auditor tidak berpengaruh signifikan terhadap kualitas audit. 


\subsubsection{Pengaruh Kompetensi Terhadap Kualitas Audit}

Pengujian terhadap hipotesis kedua dalam penelitian ini adalah untuk menguji apakah kompetensi berpengaruh signifikan terhadap kualitas audit. Setelah dilakukan uji statistik t, hasil menunjukkan bahwa kompetensi memiliki nilai signifikan 0,024 dan nilai $\mathfrak{t}_{\text {hitung }}$ kompetensi sebesar 2,319 dan $t_{\text {tabel }}$ sebesar 2,00665. Dapat disimpulkan bahwa $t_{\text {hitung }} 2,319>t_{\text {tabel }} 2,00665$ dengan tingkat signifikansi $0,024<0,05$, maka variabel independen kompetensi secara parsial berpengaruh signifikan terhadap kualitas audit. Dengan demikian $\mathrm{H}_{\mathrm{A}}$ diterima, maka dapat disimpulkan bahwa variabel kompetensi berpengaruh signifikan terhadap kualitas audit. Hal ini menunjukkan bahwa auditor dalam melakukan pemeriksaan dan pengawasaan harus memiliki pengetahuan, pengalaman dan keahlian khusus agar dapat mendeteksi dan menganalisis sebuah permasalahaan sehingga dapat meningkatkan kualitas hasil pemeriksaan yang dihasilkan.

Hasil penelitian ini sejalan dengan penelitian yang dilakukan oleh Anugerah \& Akbar (2014), Sukriah, dkk (2009), Pratomo (2016), Usman, dkk (2014) dan Mufidah (2015) yang menyatakan bahwa kompetensi berpengaruh signifikan terhadap kualitas audit. Namun penelitian ini tidak sejalan dengan penelitian yang dilakukan oleh Afriyani, dkk (2014) yang menyatakan variabel kompetensi tidak berpengaruh signifikan terhadap kualitas audit.

\subsubsection{Pengaruh Independensi Terhadap Kualitas Audit}

Pengujian terhadap hipotesis ketiga dalam penelitian ini adalah untuk menguji apakah independensi berpengaruh signifikan terhadap kualitas audit. Setelah dilakukan uji statistik t, hasil menunjukkan bahwa independensi memiliki nilai signifikansi 0,610 dan nilai $t_{\text {hitung }}$ independensi sebesar 0,514 dan $\mathrm{t}_{\text {tabel }}$ sebesar 2,00665. Dapat disimpulkan bahwa $\mathrm{t}_{\text {hitung }} 0,514<\mathrm{t}_{\text {tabel }} 2,00665$ dengan tingkat signifikansi $0,610<0,05$, maka variabel independen independensi secara parsial tidak berpengaruh signifikan terhadap kualitas audit. Dengan demikian $\mathrm{H}_{\mathrm{A}}$ ditolak, maka dapat disimpulkan bahwa variabel independensi tidak berpengaruh signifikan terhadap kualitas audit. Hal ini disebabkan pada saat pelaksanaan pemeriksaan masih belum bebas dari usaha-usaha manajerial (obyek pemeriksaan) untuk menentukan atau menunjuk kegiatan yang diperiksa, sehingga masih ada auditor yang merasa tidak perlu bekerjasama dengan manajerial atau obyek pemeriksaan. Selain itu, dalam melakukan penugasan audit terhadap auditee, dimana auditee adalah sesama PNS kemungkinan adanya hubungan kekerabatan sehingga independensi auditor terganggu baik secara faktual maupun penampilan. Maka dapat disimpulkan independensi tidak berpengaruh signifikan terhadap kualitas audit.

Hasil penelitian ini sejalan dengan penelitian yang dilakukan oleh Sukriah, dkk (2009) dan Mufidah (2015) yang menyatakan bahwa independensi tidak berpengaruh signifikan terhadap kualitas audit. Namun penelitian ini tidak sejalan dengan penelitian yang dilakukan Saputra \& Susanto (2016), Zamzami, dkk (2017), Usman, dkk (2014) dan Faizah \& Zuhdi (2013) yang menyatakan variabel independensi berpengaruh signifikan terhadap kualitas audit.

\subsubsection{Pengaruh Kompleksitas Audit Terhadap Kualitas Audit}

Pengujian terhadap hipotesis keempat dalam penelitian ini adalah untuk menguji apakah kompleksitas audit berpengaruh signifikan terhadap kualitas audit. Setelah dilakukan uji statistik t, hasil menunjukkan bahwa kompleksitas audit memiliki nilai signifikansi sebesar 0,341 dan nilai $t_{\text {hitung }}$ kompleksitas audit sebesar 0,962 dan $t_{\text {tabel }}$ sebesar 2,00665. Dapat disimpulkan bahwa $t_{\text {hitung }} 0,962<$ $\mathrm{t}_{\text {tabel }}$ 2,00665 dengan tingkat signifikansi 0,341<0,05, maka variabel independen kompleksitas audit secara parsial tidak berpengaruh signifikan terhadap kualitas audit. Dengan demikian $\mathrm{H}_{\mathrm{A}}$ ditolak, maka dapat disimpulkan bahwa variabel kompleksitas audit tidak berpengaruh signifikan terhadap kualitas audit. Hal ini disebabkan auditor dalam melaksanakan pemeriksaan dilakukan dengan cara adanya pembagian tugas audit dan dengan adanya pembagian tugas audit membuat auditor dapat lebih fokus dalam melakukan pekerjaan yang diembani sehingga penugasaan audit dapat diselesaikan dengan cepat. Dan auditor melakukan pemeriksaan hanya pada bagian-bagian tertentu saja sehingga membuat pekerjaan auditor tidak kompleks dan dapat diselesaikan tepat waktu. Maka dapat disimpulkan kompleksitas audit tidak berpengaruh terhadap kualitas audit. 
Hasil penelitian ini sejalan dengan penelitian yang dilakukan oleh Pratomo (2016) dan Anugerah \& Akbar (2014) yang menyatakan bahwa kompleksitas audit tidak berpengaruh signifikan terhadap kualitas audit. Namun penelitian ini tidak sejalan dengan penelitian yang dilakukan Hasbullah, dkk (2014) dan Sudrajat, dkk (2015) yang menyatakan variabel kompleksitas audit berpengaruh signifikan terhadap kualitas audit.

\section{SIMPULAN, KETERBATASAN DAN KONTRIBUSI PRAKTIS 5.1 Simpulan}

Penelitian ini bertujuan untuk mengetahu pengaruh skeptisime profesional auditor, kompetensi, independensi dan kompleksitas audit terhadap kualitas audit. Responden dalam penelitian ini berjumlah 57 auditor pada Inspektorat Jenderal Kementerian Lingkungan Hidup dan Kehutanan Setelah melakukan analisa dan pengujian hipotesis, maka dapat diambil kesimpulan sebagai berikut: (1) Skeptisisme Profesional Auditor berpengaruh signifikan terhadap kualitas audit (2) Kompetensi berpengaruh signifikan terhadap kualitas audit (3) Independensi tidak berpengaruh signifikan terhadap kualitas audit (4) Kompleksitas Audit tidak berpengaruh signifikan terhadap kualitas audit.

\subsection{Keterbatasan}

Keterbatasan dalam penelitian ini sebagai berikut (1) Kesulitan untuk menyebar kuesioner di Inspekorat Jenderal Kementerian Lingkungan Hidup dan Kehutanan karena auditor sedang sibuk dan sedang melakukan tugas di luar kota (2) Kuesioner tidak kembali semua dikarenakan auditor sedang sibuk dan sedang melakukan tugas diluar kota (3) Tidak semua kuesioner yang diterima dapat diolah, hal ini dikarenakan beberapa responden tidak sesuai dengan kriteria penelitian seperti memiliki lama bekerja dibawah 2 tahun dan tingkat pendidikan dibawah S1.

\subsection{Kontribusi Praktis}

Untuk peneliti selanjutnya, disarankan untuk menambahkan faktor-faktor lain sebagai variabel yang dapat mempengaruhi kualitas audit seperti tekanan anggaran waktu, etika profesi, obyektivitas dan integritas. Obyek penelitian ini hanya sebatas pada Inspektorat Jenderal Kementerian Lingkungan Hidup dan Kehutanan saja, disarankan untuk peneliti selanjutnya memperluas lingkup yang dijadikan obyek penelitian

Untuk Auditor diharapkan dapat melakukan pengawasan dan pemeriksaan yang sesuai standar yang berlaku guna untuk meningkatkan kualitas audit dan akuntanbilitas pada Inspektorat Jenderal Kementerian Lingkungan Hidup dan Kehutanan.

\section{DAFTAR PUSTAKA}

Undang-Undang Republik Indonesia Nomor 15 Tahun 2004 Tentang Pemeriksaan Pengelolaan dan Tanggung Jawab Keuangan Negara.

Peraturan Badan Pemeriksaan Keuangan Republik Indonesia Nomor 1 Tahun 2017 Tentang Standar Pemeriksaan Keuangan Negara.

Peraturan Menteri Negeri Pendayagunaan Aparatur Negara Nomor: PER/05/M.PAN/03/2008 Tentang Standar Audit Aparat Pengawasan Intern Pemerintah.

Afriyani, N,. Anugerah, R,. \& Rofika. (2014). "Pengaruh Kompetensi, Motivasi dan Skeptisme Profesional Terhadap Kualitas Audit Auditor Inspektorat Se-Provinsi Riau". JOM FEKON, Vol.2 No.2.

Agoes, Sukrisno. (2012). Auditing Petunjuk Praktis Pemeriksaan Akuntan Oleh Akuntan Publik, Edisi keempat. Jakarta: Penerbit Salemba Empat. 
Anugerah, R,. \& Akbar, S.H. (2014). "Pengaruh Kompetensi, Kompleksitas Tugas dan Skeptisme Profesional Terhadap Kualitas Audit”. Jurnal Akuntansi, Vol.2 No.2. hal 139-148.

Arens, A.A,. Elder, R.J,. Beasley, M.S. (2015). Auditing dan Jasa Assurance Pendeketan Terintegrasi Edisi Kelimabelas Jilid 1. Jakarta: Penerbit Erlangga.

Ashari, Muhammad. (2017). 14 Kementerian dan Lembaga Belum Dapat WTP. Diakses pada tanggal 6 November 2017, dari www.pikiran-rakyat.com

Asosiasi Audit Intern Pemerintah Indonesia (AAIPI). (2014). Standar Audit Intern Pemerintah Indonesia.

Badan Pemeriksa Keuangan Republik Indonesia. (2012). BPK Bahas Hasil Pemantauan Tindak Lanjut Kementerian EDSM dan KLH. Diakses pada tanggal 1 November 2017, dari www.bpk.go.id

Badan Pemeriksa Keuangan Republik Indonesia. (2017). Laporan Hasil Pemeriksaan BPK atas Laporan Keuangan Pemerintah Pusat Mengalami Peningkatan. Diakses pada tanggal 6 November 2017, dari www.bpk.go.id

Faizah \& Zuhdi, R. (2013). "Faktor-Faktor Yang Mempengaruhi Kualitas Pemeriksaan”. JAFF, Vol.1 No.2, hal 83-98.

Felisiani, Theresia. (2017). Kasus Suap Dirjen Perhubungan Laut, KPK Periksa 3 Orang. Diakses pada tanggal 7 November 2017, dari www.tribunnews.com

Ghozali, I. (2016). Aplikasi Analisis Multivariete Dengan Program IBM SPSS 23. Semarang: Penerbit Universitas Diponegoro.

Harahap, S.S. (2013). Teori Akuntansi. Jakarta: Rajawali Pers.

Hasbullah,. Sulindawati, N.L.D.E,. \& Herawati, N.T. (2014). "Pengaruh Keahlian Audit, Kompleksitas Tugas dan Etika Profesi Terhadap Kualitas Audit". E-Journal S1 Ak Universitas Pendidikan Ganesha, Vol.2 No.1.

Institut Akuntan Publik Indonesia. (2013). Standar Profesional Akuntan Publik. Jakarta: Salemba Empat.

Jensen \& Meckling. (1976). "Theory of The Firm: Managerial Behavior, Agency Costs and Ownership Structure". Journal of Financial Economics, Vol.3 No.4, pp 305-306.

Kementerian Lingkungan Hidup dan Kehutanan. (2015). Statistik Kementerian Lingkungan Hidup dan Kehutanan. Diakses pada tanggal 12 September 2017, dari www.menlhk.go.id

Lubis, A.I.. (2010). Akuntansi Keperilakuan. Jakarta: Salemba Empat.

Mufidah. (2015). "Analisis Pengaruh Independensi, Obyektivitas, Integritas, Kompentensi, Pengalaman Kerja dan Skeptisisme Profesional Terhadap Kualitas Hasil Pemeriksaan di Lingkungan Inspektorat Provinsi Jambi”. Jurnal Ilmiah Universitas Batanghari Jambi, Vol.15 No.2.

Pratomo, D,. (2016). "Pengaruh Kompetensi, Kompleksitas Tugas dan Tekanan Anggaran Waktu Terhadap Kualitas Audit Internal Pemerintah Daerah". Jurnal Akuntansi dan Bisnis, Vol.16 No.2, hal 123-133.

Rahayu, S.K,. \& Suharyati, E. (2013). Auditing Konsep Dasar Pedoman Pemeriksaan Akuntan Publik. Yogyakarta: Penerbit Graha Ilmu. 
Rahmawati. (2012). Teori Akuntansi Keuangan. Yogyakarta: Graha Ilmu.

Rai, I Gusti Agung. (2008). Audit Kinerja Pada Sektor Publik. Jakarta: Grafindo.

Robbins, S.P. (2006). Perilaku Organisasi. Jakarta: PT.Indeks Kelompok Gramedia.

Saputra, A,. \& Susanto, D.S,. (2016). "Kompetensi, Independensi, Profesionalisme dan Etika Profesi Audit Internal Auditor Terhadap Kualitas Audit di Inspektorat Jenderal Kementerian Ketenagakerjaan”. Jurnal Riset Akuntansi dan Perpajakan, Vol.3 No.2. hal 21-32.

Sudrajat, L.A,. Rifai, A,. \& Pituringsih, E. (2015). "Pengaruh Time Budget Pressure, Kompleksitas Audit dan Skeptisisme Profesional Auditor Terhadap Kualitas Hasil Pemeriksaan". Jurnal Akuntansi Aktual, Vol.3 No.2.

Sugiyono. (2014). Metode Penelitian Manajemen. Bandung: Penerbit Alfabeta.

Sukriah, Ika,. Akram,. Inapty, B.A. (2009). "Pengaruh Pengalaman Kerja, Independensi, Obyektivitas, Integritas dan Kompetensi Terhadap Kualitas Hasil Pemeriksaan”. Simposium Naional Akuntansi XII. Pamulang.

Tuanakotta, T.M. (2013). Audit Berbasis ISA (International Standards on Auditing). Jakarta: Salemba Empat.

Usman, A,. Sudarma, M,. Habbe, H,. \& Said, D. (2014). "Effect of Competence Factor, Independence and Attidue Against Professional Auditor Audit Quality Improve Performance in Inspectorate (Inspectorate Emprical Study in South Sulawesi Provinsi)". Journal of Business and Management, Vol.16 Issue 1.

Yuniati, Ninik. (2017). Banyak OTT KPK, Jokowi Soroti Lemahnya Kinerja Inspektorat Pemerintah. Diakses pada tanggal 6 November 2017, dari http://kbr.id

Zamzami, F,. Tantri, S.N,. \& Timur, R.P. (2017). "Effect of Auditor Independence and Experience, Size of Client's Financial Health and Audit Fee on Audit Quality: An Empirical Study on Public Accounting Firms in Indonesia". Journal of Economic, Business and Management, Vol.5 No.1 